\section{Preparing polyA-Con- taining RNA Internal Standards for Multiplex Competitive RT-PCR}

BioTechniques 29:454-458 (September 2000)

PCR-based strategies such as com petitive RT-PCR or semiquantitative RTPCR are commonly used for quantitating low-abundance mRNA transcripts (4,7-9). Competitive RT-PCR relies on amplifying the same target with a known amount of a competitor/reference sequence and comparing the relative amounts of the two PCR products. To improve the sensitivity and accuracy of these methods, often expensive and cumbersome techniques such as HPLC or the use of radioactivity have been used for PCR product quantitation $(1,2$, $6,10)$. Ideally, a good competitor should share with the mRNA target the same primers and most of the sequence, and the resulting PCR products should be easily discernible from one another and quantified $(5,11)$. Usually, a single target is quantified by competitive RTPCR, and several reactions would be needed to quantitate multiple target sequences in a given RNA sample. We present here a versatile method to synthesize competitor polyA-extended RNA sequences, which are ideal for multiplex RT-PCR in which reverse transcription may be primed with oligo dT. We show that this multiplex competitive RT-PCR approach can be used to detect mRNA species as low as $10^{3}$ molecules/reaction.

A rapid PCR-based method to synthesize internal standards for competitive PCR has been previously described (3). Briefly, the target sequences are amplified with two primers, one conventional sense primer (Figure 1A, primer a) to be used for the subsequent experiments and a modified antisense primer (Figure 1A, primer $b_{1}$ ). The resulting PCR products, which by design are approximately $10 \%$ shorter than the target sequences (Figure 1A), are gel purified and reamplified with a second pair of primers containing, respectively, a HindIII site (sense primer) and oligo $\mathrm{dT}_{21}$ followed by an $\mathrm{XbaI}$ site (antisense primer) (Figure 1B). These two
PCR amplification steps can be com bined, but the required primers would be quite long and there would be a risk of poor amplification. The PCR products are then digested with the two enzymes, gel purified and directionally cloned into $\mathrm{pGem}^{\circledR} 4 \mathrm{Z}$ (Promega, Milan, Italy) (Figure 1C). The recombinant plasmids are linearized with $X b a \mathrm{I}$, and RNA synthesis is performed in vitro using a commercially available kit (Riboprobe ${ }^{\circledR}$; Promega) with minor modification to the manufacturer's instructions (Figure 1D).

Briefly, $2 \mu \mathrm{g}$ linearized plasmid is incubated in $40 \mathrm{mM}$ Tris- $\mathrm{HCl}(\mathrm{pH} 7.9$ at $25^{\circ} \mathrm{C}$ ), $10 \mathrm{mM} \mathrm{NaCl}, 6 \mathrm{mM} \mathrm{MgCl} 2$, $10 \mathrm{mM}$ DTT, $2 \mathrm{mM}$ spermidine, $0.05 \%$ Tween ${ }^{\circledR}(20,0.5 \mathrm{mM}$ each ATP, GTP, CTP and UTP and 40 U T7 RNA polymerase in a final volume of $100 \mu \mathrm{L}$ for $2 \mathrm{~h}$ at $37^{\circ} \mathrm{C}$. The samples are heated at $95^{\circ} \mathrm{C}$ for $2 \mathrm{~min}$ and placed on wet ice. Twenty microliters of the mixture is

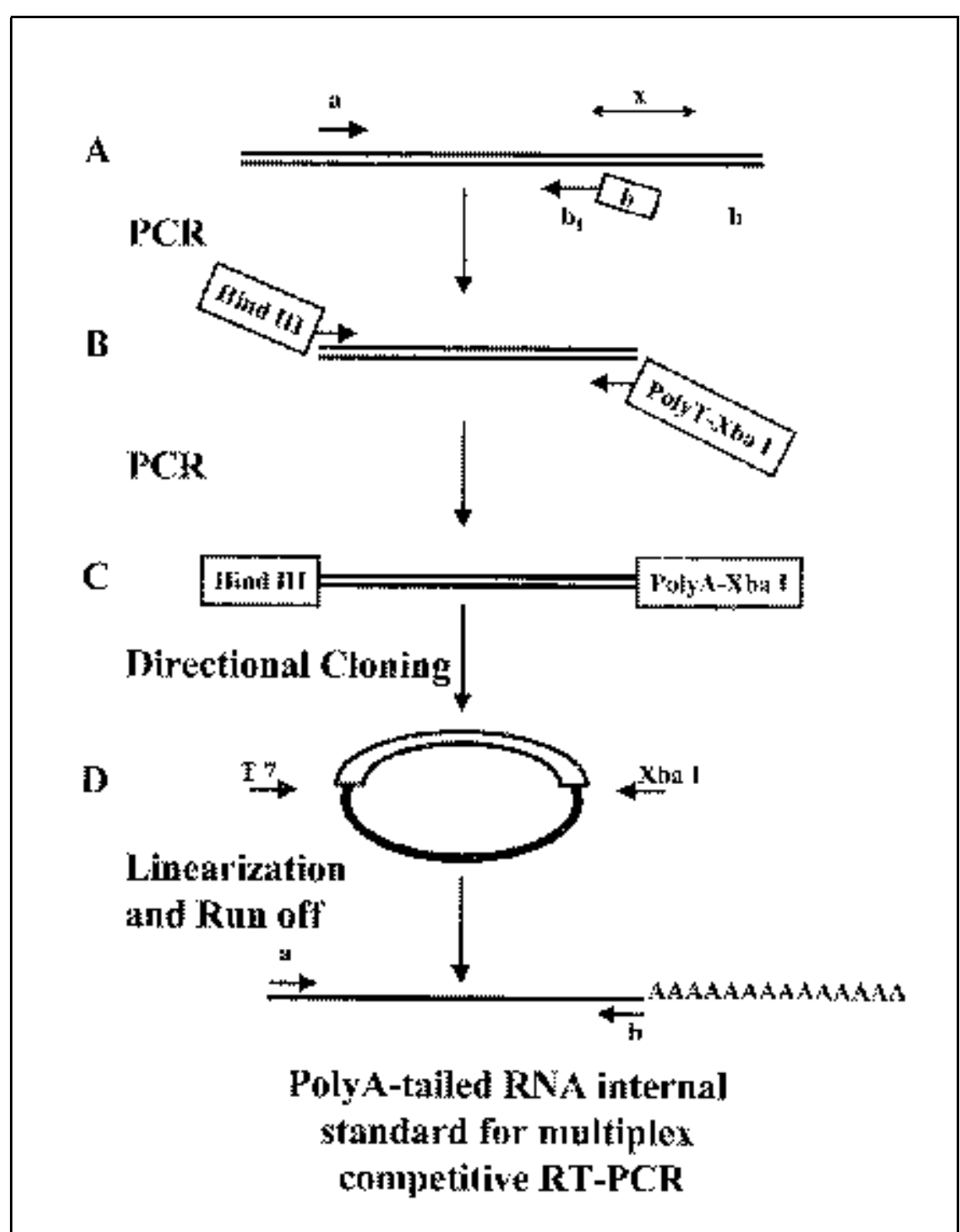

Figure 1. polyA-extended RNA internal standard synthesis. (A) PCR-based internal standard synthesis. $a=$ sense primer, $b=$ antisense primer to be used for subsequent experiments, $b_{1}=$ internal standard (IS) synthesis antisense primer, extended with primer $\mathrm{b}$ sequence and $\mathrm{x}=$ deleted sequence. The resulting PCR product is designed to be approximately $10 \%$ shorter than the target sequence. (B) Reamplification of the internal standard with primers containing Hin $\mathrm{dIII}$ (sense) and oligo $\mathrm{dT}_{21}-\mathrm{Xba \textrm {I }}$ (antisense). (C) Directional cloning of the internal standard after digestion with HindIII and XbaI. (D) Linearization and in vitro RNA internal standard synthesis. 
then incubated in a final volume of 35 $\mu \mathrm{L} 1 \times$ transcription buffer containing $40 \mathrm{U}$ RNasin ${ }^{\circledR}$ and 5 U RQ1 RNaseFree DNase for $1 \mathrm{~h}$ at $37^{\circ} \mathrm{C}$. The RNA is extracted with TE-saturated phenol:chloroform, $\mathrm{pH}$ 5.6, once with chloroform:isoamyl alcohol (24:1) and precipitated with 0.5 vol $7.5 \mathrm{M}$ ammonium acetate and 2.5 vol ethanol at $-80^{\circ} \mathrm{C}$ for $12 \mathrm{~h}$ before centrifugation at $31000 \times g$ for $90 \mathrm{~min}$ at $4^{\circ} \mathrm{C}$. The pellet is washed with $70 \%$ ethanol and resuspended in DEPC-treated water in a final volume of $15 \mu \mathrm{L}$, and the unincorporated nucleotides are removed via Sephadex ${ }^{\circledR}$ G-50 columns (Amersham Pharmacia Biotech, Cologno Monzese, Italy). To confirm the integrity of the in vitro-synthesized RNA, $1 \mu \mathrm{L}$ each synthesized RNA is reverse transcribed using a $5^{\prime}(\mathrm{T})_{34} \mathrm{~V}^{\prime}(\mathrm{V}=\mathrm{A}$ or $\mathrm{G}$ or $\mathrm{C})$ primer and amplified with the corresponding specific primer pair. To verify the absence of cDNA carry-over, an equal amount of synthesized RNA is amplified with the same primer pair, but without reverse transcription. These products are run on an agarose gel. Once it is confirmed that RT-PCR results in the expected product and that PCR without reverse transcription does not, the RNA is quantified by a spectrophotometer and $10 \mu \mathrm{g}$ yeast tRNA is added to each sample as a carrier. Finally, the samples are serially diluted with DEPC-treated water to $10^{7}-10^{3}$ molecules $/ \mu \mathrm{L}$ and stored at $-80^{\circ} \mathrm{C}$. Experiments demonstrated that the reverse transcription reaction of polyA-extended internal standards performed with $5^{\prime}(\mathrm{T})_{34} \mathrm{~V}^{\prime}$ primer is at least as efficient as with random hexamers or gene-specific primers (data not shown).

The method was validated by multiplex competitive RT-PCR of the $\alpha-1, \alpha$ 2 and $\beta-1$ thyroid hormone receptor isoform mRNAs. Briefly, aliquots of 100 ng human myocardium total RNA were reverse transcribed in $50 \mathrm{mM}$ Tris- $\mathrm{HCl}$ $\left(\mathrm{pH} 8.3\right.$ at $25^{\circ} \mathrm{C}$ ), $75 \mathrm{mM} \mathrm{KCl}, 3 \mathrm{mM}$ $\mathrm{MgCl}_{2}, 10 \mathrm{mM}$ DTT, $200 \mu \mathrm{M}$ each dNTP, $10 \mu \mathrm{M} \mathrm{5}$ 5 $^{\prime}()_{34} \mathrm{~V}^{\prime}$ primer, $20 \mathrm{U}$ RNasin and $200 \mathrm{U}$ MMLV reverse transcriptase (Promega) in a final volume of $25 \mu \mathrm{L}$ in the presence of $10^{7}-10^{3}$ molecules of internal standards for $2 \mathrm{~h}$ at $37^{\circ} \mathrm{C}$. The reaction was terminated by heating at $70^{\circ} \mathrm{C}$ for $15 \mathrm{~min}$. Five microliters of the reaction was then amplified in a final volume of $50 \mu \mathrm{L}$ in $10 \mathrm{mM}$ Tris- $\mathrm{HCl}\left(\mathrm{pH} 9.0\right.$ at $25^{\circ} \mathrm{C}$ ), $50 \mathrm{mM} \mathrm{KCl}$, $0.1 \%$ Triton ${ }^{\circledR} \mathrm{X}-100,2.5 \mathrm{mM} \mathrm{MgCl}_{2}$, $200 \mu \mathrm{M}$ each dNTP and $10 \mu \mathrm{M}$ each primer. After an initial denaturation of 2 min at $94^{\circ} \mathrm{C}, 5 \mu \mathrm{L}$ enzyme solution, $1 \mathrm{U}$ Taq DNA polymerase (Promega) in 10 $\mathrm{mM}$ Tris- $\mathrm{HCl}\left(\mathrm{pH} 9.0\right.$ at $\left.25^{\circ} \mathrm{C}\right), 50 \mathrm{mM}$ $\mathrm{KCl}$ and $0.1 \%$ Triton $\mathrm{X}-100$, was added to the reaction, and 33 cycles of $54^{\circ} \mathrm{C}$ for $1 \mathrm{~min}, 72^{\circ} \mathrm{C}$ for $1 \mathrm{~min}$ and $94^{\circ} \mathrm{C}$ for 1 min were performed followed by a final step of $72^{\circ} \mathrm{C}$ for $10 \mathrm{~min}$. The samples were run on a $3 \%$ agarose gel, and the amount of mRNA was estimated as the equivalence between each target and internal standard band intensity (Figure 2).

The data demonstrate that an accurate estimation of low-abundance mRNA transcripts can be easily performed through multiplex competitive RT-PCR from small amounts of total RNA. The use of gene-specific RNA internal standards that share the target gene primers and most of the sequence results in virtually identical efficiencies in reverse transcription and amplification between the target mRNA and the RNA internal standard, thus improving accuracy. The presence of a polyA overhang at the $3^{\prime}$ end of the RNA internal standards represents a significant advantage over other techniques because the entire pool of mRNA may be converted to cDNA by reverse transcription with oligo dT, and only one aliquot needs to be used for the multiplex PCR, and the remaining cDNA is available for other experiments. This is especially important with tissue samples of small size (e.g., human myocardium biopsies). Unlike the reverse transcription performed with random hexamers, the use of an oligo dT primer allows the selective amplification of nondegraded molecules, a useful advantage in experiments involving highturnover transcripts. Moreover, the visualization and quantification steps proposed in this method are extremely simple with no digestion, radiolabeling or membrane transfer steps because the PCR products are visible on an ethidium bromide-stained agarose gel. No degradation of RNA internal standards was observed in a six-month period even at the lowest concentration $\left(10^{3}\right.$ molecules/ $\mu \mathrm{L})$.

Optimization of PCR conditions for 


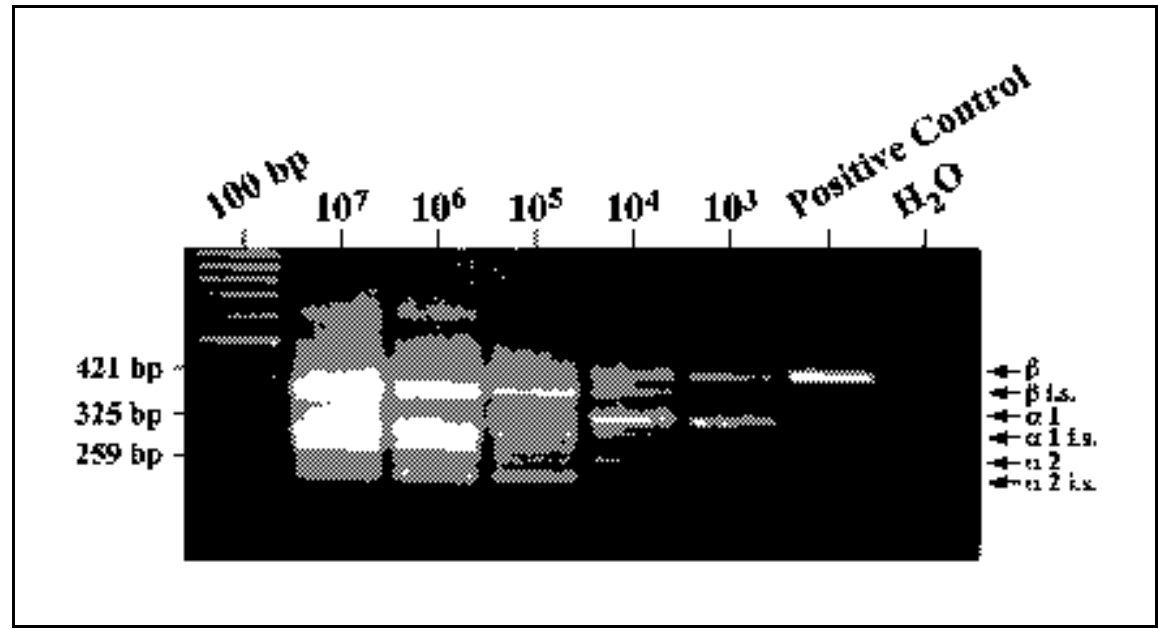

Figure 2. Multiplex competitive RT-PCR. Determination of thyroid hormone receptor isoform mRNAs in human myocardium needle biopsy. Aliquots of $100 \mathrm{ng}$ total human myocardium RNA were reverse transcribed in the presence of $10^{7}-10^{3}$ molecules of polyA-extended RNA internal standards (i.s.) for human thyroid hormone receptor $\alpha-1, \alpha-2$ and $\beta-1$ isoforms. Aliquots of the reaction were then amplified using target-specific primers (see text for details), and agarose gel electrophoresis, ethidium bromide staining and UV transillumination were performed. In this myocardial sample, we found that the amount of $\alpha-1, \alpha-2$ and $\beta-1$ were $5 \times 10^{4}, 1 \times 10^{4}$ and $5 \times 10^{4}$, respectively. The experiment was performed in triplicate with nearly identical results. No difference was observed when the experiment was performed as single competitive RT-PCR for each isoform. The PCR product under $259 \mathrm{bp}$ is unexplained and likely represents an extraneous PCR product caused by mispriming between the $\alpha-1$ and $\alpha-2$ isoforms.

several templates, as required by multiplex PCR, may not be trivial and needs to be individualized for each application. In this set of experiments, primer sequences were carefully chosen to avoid $3^{\prime}$ homologies, conserved sequences and potential secondary structure, and to generate PCR products of sufficiently different sizes to be visualized on an agarose gel. Each reaction was initially optimized with magnesium (1.5-3 $\mathrm{mM}$ range) and annealing temperature $\left(52^{\circ} \mathrm{C}-58^{\circ} \mathrm{C}\right)$ titration experiments before attempting the multiplex approach. It is possible that the conditions required in this system have been particularly favorable and that other sequences would require more extensive modifications. The use of hot-start PCR techniques further reduces the risk of generating primerdimers and other extraneous PCR products. Finally, the purification of the RNA internal standards from unincorporated nucleotides and cDNA carryover represents a critical step for the subsequent accurate quantification of the RNA internal standards.

In conclusion, we believe that the use of multiplex competitive RT-PCR with polyA-extended RNA internal standards represents a simple and versa- tile method to accurately quantitate the amounts of multiple RNA species with minimal starting material. A possible future application of this method is the production of panels of polyA-extended RNA internal standards to be used to quantify multiple messages from small tissue sources (e.g., needle biopsies).

\section{REFERENCES}

1.Bachmair, F., C. Huber and G. Daxenbichler. 1999. Quantitation of gene expression by means of HPLC analysis of RT-PCR products. Clin. Chim. Acta 279:25-34.

2.Borson, N.D., M.A. Strausbauch, P.J. Wettstein, R.P. Oda, S.L. Johnston and J.P. Landers. 1998. Direct quantitation of RNA transcripts by competitive single-tube RTPCR and capillary electrophoresis. BioTechniques 25:130-137.

3.Celi, F.S., M.E. Zenilman and A.R. Shuldiner. 1993. A rapid and versatile method to synthesize internal standards for competitive PCR. Nucleic Acids Res. 21:1047.

4.Colle, J.H., P.B. Falanga, M. Singer, B. Hevin and G. Milon. 1997. Quantitation of messenger RNA by competitive RT-PCR: a simplified read out assay. J. Immunol. Methods 210:175-184.

5.Freeman, W.M., S.J. Walker and K.E. Vrana. 1999. Quantitative RT-PCR: pitfalls and potential. BioTechniques 26:112-125.

6.Hall, L.L., G.R. Bicknell, L. Primrose, J.H. Pringle, J.A. Shaw and P.N. Furness. 1998. Reproducibility in the quantification of
mRNA levels by RT-PCR-ELISA and RT competitive-PCR-ELISA. BioTechniques 24:652-658.

7.Kobayashi, H., Y. Takemura, H. Miyachi, M. Kawabata, S. Mori, Y. Kawai, K. Furihata, S. Sekiguchi and K. Watanabe. 1997. Quantitative analysis of human multidrug resistance 1 (MDR1) gene expression by nonisotopic competitive reverse transcriptase polymerase chain reaction assay. J. Clin. Lab. Anal. 11:258-266.

8.Liu, Z.F. and D.R. Burt. 1998. A synthetic standard for competitive RT-PCR quantitation of 13 GABA receptor type A subunit mRNAs in rats and mice. J. Neurosci. Methods 85:8998.

9.Miyake, H., I. Okamoto, I. Hara, K. Gohji, K. Yamanaka, S. Arakawa, S. Kamidono and H. Saya. 1998. Highly specific and sensitive detection of malignancy in urine samples from patients with urothelial cancer by CD44v8-10/CD44v10 competitive RT-PCR. Int. J. Cancer 79:560-564.

10.Overbergh, L., D. Valckx, M. Waer and C. Mathieu. 1999. Quantification of murine cytokine mRNAs using real time quantitative reverse transcriptase PCR. Cytokine 11:305312.

11.Zimmermann, K. and J.W. Mannhalter. 1996. Technical aspects of quantitative com petitive PCR. BioTechniques 21:268-279.

The authors wish to acknowledge the comments and helpful suggestions of Dr. Alan R. Shuldiner and Dr. John C. McLenithan. The financial support of TelethonItaly (grant no. E.763) is gratefully acknowledged. Address correspondence to Dr. Francesco Saverio Celi, I Cattedra di Endocrinologia, Dipartimento di Medicina Sperimentale e Patologia, Viale Regina Elena, 324, 00161 Rome, Italy. e-mail: francescosaverio@uniromal.it

Received 8 November 1999; accepted 26 April 2000.

\section{F.S. Celi, D. Mentuccia, L. Proietti-Pannunzi, C.R.T. di Gioia and M. Andreoli Università degli Studi di Roma Rome, Italy}

